\title{
EFFECT OF POULTRY FEED SUPPLEMENTED WITH HYPERICUM PERFORATUM EXTRACT AND VIRGINIAMYCINE ON GROWTH PERFORMANCE, SOME IMMUNE RESPONSES AND INTESTINAL MICROBIAL POPULATION OF BROILERS
}

\author{
Sayyed Masoud Davoodi, Farshid Kheiri, Yaser Rahimian, Researchers \\ Islamic Azad University, Isfahan, Iran \\ E-mail: smd1392@yahoo.com
}

\begin{abstract}
This study investigated the effect of adding Hypericum perforatum to drinkable water in comparison to virginiamycine on performance of broilers and thus on improvement and increase welfare and growth. A total of 400 , one day old broiler chicks with an average weight of $37 \pm 50 \mathrm{~g}$ were divided into 5 treatment groups and were further subdivided into 4 replicates. The treatments were divided as basal diet with no Hypericum perforatum extract kept as control, and for others $150 \mathrm{mg} / \mathrm{l}$ (S1), $200 \mathrm{mg} / \mathrm{l}$ (S2) and $250 \mathrm{mg} / \mathrm{l}$ (S3) of herbal extract in their Drinking water and virginiamycine (S4) were used respectively. The live body weight gains and feed consumption of birds were measured individually feed conversion efficiency were calculated weekly. At the end of the trial for investigating the effect of using Hypericum perforatum and virginiamycine on performance of broilers, 3 birds form each replicates were slaughtered and some blood samples were taken for determination HDL, LDL, Triglyceride levels and antibody titer against Newcastle vaccine. Data showed that use of S1, S2 and S3 and S4 increased FI significantly $(\mathrm{P}<0.05)$ in comparison to control. Also BW and Pre-slaughter weigh at the end of the experiment were also significantly higher $(\mathrm{P}<0.05)$ in experimental groups compared to the control. Liver percentage was significantly induced were broilers fed with experimental diets $(p<0.05)$. There were significant differences $(p<0.05)$ for heart percentage between treatments. Using of herbal plant extract could reduce abdominal fat percentage statistically $(p<0.05)$.Percentage of gizzard was higher in the control group and it was at the lowest in virginiamycine group $(p<0.05)$. triglyceride, cholesterol and LDL level decreased significantly in the treated groups while HDL level increased significantly in S1, S2, S3and S4. Antibody titers were significantly higher $(\mathrm{p}<0.05)$ when broilers were fed by $\mathrm{S} 1, \mathrm{~S} 2$, S3and $\mathrm{S} 4$. It was determined that herbal and virginiamycine had significant effects on $H I$ test $(p<0.05)$ that compared to control group. Data showed that E. coli population decreased in S1, S2, S3 and S4 while Lactobacillus population increased significantly in $S 4, S 3, S 2$ and $S 1$ respectively $(p<0.05)$.
\end{abstract}

\section{KEY WORDS}

Hypericum perforatum; Virginiamycine; Performance; Hematological parameters; Broilers.

St Johnson wort (Hypericum perforatum L.) is a medicinal plant containing many polyphenolic compounds, including flavonoids and phenolic acids with antidepressant and antiinflammatory properties.

Hypericum perforatum is a several-years-old plant from Hypericum family which is used as medical plant due to its multiple essences and alkaloid and glycoside ingredients. Known allelopathing in plants which have toxic properties mostly include alkaloid, glycoside and phenolic ingredients. It is widely known as a herbal treatment for depression (Alipour et al., 2013). In some countries, such as Germany, it is commonly prescribed for mild to moderate depression, especially in children and adolescents (Brenner et al., 2000; Bourke, 1997).Scientists showed that some active constituents in Hypericum perforatum are a pinen, sammene, $\beta$ pomene, myrsen, $\alpha$ terpenin, Limonene, ocimene, $y$ terpinene, terpinene and $\beta$ curpinene. It is proposed that the mechanism of action of Hypericum perforatum is due to the inhibition of reuptake of certain neurotransmitters ().A major constituent chemical, hyperforin, that it has also displayed antibacterial properties against Gram-positive bacteria (). The positive 
effects that have been observed are generally attributed to hyperforin due to its possible antibacterial and anti-inflammatory effects (Evstifeeva et al., 1996; Mennini et al., 2004; Sakar et al., 1990). Also hypericin and pseudohypericin that they are in Hypericum perforatum have shown both antiviral and antibacterial activities, It is believed that these molecules can bind nonspecifically to viral and cellular membranes and can result in photo oxidation of the pathogens to kill them (Franklin et al., 2004; Kraus et al., 1990).Virginiamycine is a streptogramine antibiotic similar to pristinamycine and quinupristin/dalfopristin. It is a combination of Virginiamycin M1 and virginiamycine S1. It was used in the fuel ethanol industry to prevent microbial contamination. It was also used in agriculture, specifically in livestock, to accelerate the growth of the animals and to prevent and treat infections (Teymourizadeh et al., 2009). Some researchers showed that use of virginiamycine in broiler chicks decreased intestinal $\mathrm{E}$. coli population and increased Lactobacillus population (ghaedi et al., 2014; Faghani et al., 2014).Also they found that treatment with virginiamycine at suggested dosages has a beneficial Effect on body weight gain and feed conversion efficiency in poultry. Aghili et al, (2014) showed that use of Hypericum perforatum slightly improved Ig G titer but significantly increased the number of leukocytes and monocytes at $200 \mathrm{mg}$, and neutrophils at $400 \mathrm{mg}$. The Hypericum perforatum decreased BW at $100 \mathrm{mg}$ and $200 \mathrm{mg}$ with no damage on spleen for Rats. This study was investigated the effects of Hypericum perforatum extract on performance, Feed intake (FI), body weight (BW), and some hematological and $\mathrm{HI}$ test against Newcastle decease vaccine in broiler chicks.

\section{MATERIALS AND METHODS}

This experiment was carried out at the poultry farm of animal science college, Islamic Azad University, ShahreKord branch, Iran. A total of 400 one day old broiler chicks with an average weight of $37 \pm 50 \mathrm{~g}$ were divided into five treatment groups and were further subdivided into four replicates. The Hypericum perforatum was purchased from local market in Isfahan. For preparation of hydro alcoholic extract, air-dried and powdered fruits of the plant were macerated with ethyl alcohol for $48 \mathrm{~h}$.

Table 1 - Composition of the experimental diets on the study

\begin{tabular}{lccc}
\hline Ingredients \% & $0-14$ (days old) & 15-29 (days old) & 29-42 (days old) \\
\hline Corn & 51.64 & 56.61 & 60.37 \\
Soybean meal & 37.74 & 32.30 & 27.81 \\
Wheat & 5 & 5 & 5 \\
Oil & 1.40 & 2.03 & 2.84 \\
DCP & 1.56 & 1.47 & 1.39 \\
Oyster shells & 1.17 & 1.13 & 1.08 \\
Methionine D-L & 0.30 & 0.29 & 0.27 \\
Lysine-L & 0.13 & 0.13 & 0.30 \\
Nacl & 0.26 & 0.24 & 0.14 \\
Vitamin Premix & 0.3 & 0.3 & 0.3 \\
Mineral Premix* & 0.3 & 0.3 & 0.3 \\
Virginiamycine & 0.2 & 0.2 & 0.2 \\
\hline Calculated nutrient content & & & \\
\hline ME(Kcal/Kgr) & 2.850 & 2.950 & 3.050 \\
CP (\%) & 22 & 20 & 0.5 \\
Ca (\%) & 0.90 & 0.85 & 0.40 \\
Available Phosphorus (\%) & 0.45 & 0.42 & 1.16 \\
Lysine (\%) & 1.35 & 1.20 & 0.15 \\
Na (\%) & 0.16 & 0.15 & 0.85 \\
Methionine+Cystine (\%) & 0.97 & 0.87 & \\
\hline
\end{tabular}

Supplied Per Kilogram Of Feed: 7.500 IU of vitamin A, 2000IU vitamin D3, 30 Mg vitamin E,1.5 $\mu$ g vitamin B12,2Mg B6,5 Mg Vitamin K,5 Mg vitamin B2,1 Mg vitamin B1,40 Mg nicotinic acide,160 $\mu$ gitamin Biothine,12 Mg Calcium pantothenate, $1 \mathrm{MgFolic}$ acid $20 \mathrm{Mg} \mathrm{Fe,71} \mathrm{Mg} \mathrm{Mn,100 \mu g} \mathrm{Se,37Mg} \mathrm{Zn,6} \mathrm{Mg} \mathrm{Cu,1.14} \mathrm{Mg} \mathrm{l,400} \mu \mathrm{Cl}$. 
The extract was then shacked, filtered and evaporated in a rotating evaporator under reduced pressure until dryness. Evaporation and solvent removal of hydro alcoholic extract gave semi-solid masses. The treatments were divided as basal diet with no Hypericum perforatum extract kept as control, and for others $100 \mathrm{mg} / \mathrm{l}$ (S1), $150 \mathrm{mg} / \mathrm{l}$ (S2) and $200 \mathrm{mg} / \mathrm{l}$ (S3) of Hypericum perforatum extract in their drinking water and virginiamycine (S4) were used respectively. The chemical composition of the experimental basal diets is shown in Table 1. Diets and fresh water were provided adlibitum during this experiment. Chicks were vaccinated against Newcastle disease. The live body weight gains and feed consumption of birds were measured individually feed conversion efficiency were calculated weekly. At the end of experimental period, 3 birds form each replicates (totally 40 birds) were slaughtered by cervical dislocation method for determination of other parameters. Dressing percentage was calculated free from giblets and the Organs were weighed separately as percentage of carcass weight. Also illeocecal intestinal microbial population of E.coli and Lactobacillus were investigated.

Evaluation of some blood parameters. After $12 \mathrm{~h}$ of fasting, blood samples were taken from the brachial vein from two birds per replicate and stored at refrigerator at $4^{\circ} \mathrm{C}$. Individual serum samples were analyzed for total cholesterol, high density lipoprotein (HDL), low density lipoprotein (LDL) cholesterol and triglyceride, by an automatic biochemical analyzer following the instructions of the corresponding reagent kit (Pars Azmoon Co., Teheran, Iran).

Vaccination and evaluation the antibody titer obtained from Newcastle diseases vaccine. B1 vaccine, dead vaccine that made by Razi research and serum producing institute, were used as eye drop and subcutaneous injection on $11^{\text {th }}$ day. Lasota vaccine, made by Veternia Co, on $19^{\text {th }}$ day for Newcastle vaccine and Newcastle vaccine, made by Veternia Co, was used on $38^{\text {th }}$ day. Blood sampling was conducted by cutting off the chicks' head followed to sampling from wing area, then the samples transferred to the laboratory and the samples' serum separated by $3000 \mathrm{rpm}$ centrifuging for $15 \mathrm{~min}$ in order to do the HI test on serum samples.

Data analysis. Data were collected and analyzed using the General linear model procedure of SAS (2001). Differences between means were analyzed by Duncan's multiple ranges test and $P$ value less than 0.05 was considered as significant.

\section{RESULTS AND DISCUSSION}

Table 2 data showed that use of S1, S2 and S3 and S4 increased FI significantly $(P<0.05)$ in comparison to control. Also BW and Pre-slaughter weigh at the end of the experiment were also significantly higher $(\mathrm{P}<0.05)$ in experimental groups compared to the control.

Table 2 - The effect of added experimental diets on broilers performance

\begin{tabular}{cccccc}
\hline Treatments & $\mathrm{Fl}(\mathrm{g} / \mathrm{d})$ & $\mathrm{BW}(\mathrm{g} / \mathrm{d})$ & $\mathrm{FCR}$ & $\mathrm{Fl}(\mathrm{kg})$ & Pre-slaughter weigh $(\mathrm{g})$ \\
\hline Control & $85.21^{\mathrm{d}}$ & $41.54^{\mathrm{d}}$ & $2.07^{\mathrm{a}}$ & $3580^{\mathrm{a}}$ & $1745^{\mathrm{d}}$ \\
$\mathrm{S}_{1}$ & $86.32^{\mathrm{c}}$ & $42.00^{\mathrm{c}}$ & $2.05^{\mathrm{b}}$ & $3620^{\mathrm{c}}$ & $1764^{\mathrm{c}}$ \\
$\mathrm{S}_{2}$ & $87.84^{\mathrm{c}}$ & $42.45^{\mathrm{c}}$ & $2.05^{\mathrm{b}}$ & $3688^{\mathrm{c}}$ & $1791^{\mathrm{c}}$ \\
$\mathrm{S}_{3}$ & $89.36^{\mathrm{b}}$ & $44.37^{\mathrm{b}}$ & $2.02^{\mathrm{c}}$ & $3753^{\mathrm{b}}$ & $1851^{\mathrm{b}}$ \\
$\mathrm{S}_{4}$ & $91.24^{\mathrm{a}}$ & $46.14^{\mathrm{a}}$ & $1.97^{\mathrm{a}}$ & $3832^{\mathrm{a}}$ & $1937^{\mathrm{a}}$ \\
\hline $\mathrm{MSE}$ & 0.497 & 0.874 & 0.158 & 0.765 & 1.143 \\
\hline
\end{tabular}

*Means within row with no common on letter are significantly different $(p<0.05)$.

Ghaedi et al, (2014) showed that use of virginiamycine could affect on feed intake and lead to better FCR on broiler chicks. Also Faghani et al,(2014) showed that use of virginiamycine antibiotic could increase feed intake and body weight gain in broilers chicks. Landy et al, (2012) showed that Antibiotic supplementation increased body weight at different periods compared to other groups, but it was not significant at day 14 of age. They showed that Antibiotic supplementation significantly $(P<0.05)$ increased feed intake during growth period than those fed 
diet containing $10 \mathrm{~g} / \mathrm{kg}$ of Hypericum perforatum diet. Antibiotics may control and limit the growth and colonization of a variety of pathogenic and nonpathogenic species of bacteria in chicks gut (Ferket, 2004). Mentioned findings about rats stress reduction conform to the present study's findings; such that the herb's extract caused mortality and FCR reduction in treatment groups.

Data from table 3 showed that liver percentage was significantly induced were broilers fed with experimental diets $(\mathrm{p}<0.05)$.

Table 3 - The effect of used experimental diets on carcass traits of broilers

\begin{tabular}{cccccccc}
\hline Treatments & $\begin{array}{c}\text { Abdominal Fat } \\
(\%)\end{array}$ & $\begin{array}{c}\text { Liver } \\
(\%)\end{array}$ & $\begin{array}{c}\text { Borsal.f } \\
(\%)\end{array}$ & $\begin{array}{c}\text { Cecum } \\
(\%)\end{array}$ & $\begin{array}{c}\text { Gizzard } \\
(\%)\end{array}$ & $\begin{array}{c}\text { Heart } \\
(\%)\end{array}$ & $\begin{array}{c}\text { Carcass Yield } \\
(\%)\end{array}$ \\
\hline Control & $2.32^{\mathrm{a}}$ & $2.81^{\mathrm{a}}$ & $0.110^{\mathrm{d}}$ & $1.22^{\mathrm{a}}$ & $3.75^{\mathrm{a}}$ & $0.512^{\mathrm{d}}$ & $70.4^{\mathrm{b}}$ \\
$\mathrm{S}_{1}$ & $2.15^{\mathrm{b}}$ & $2.61^{\mathrm{b}}$ & $0.118^{\mathrm{d}}$ & $1.05^{\mathrm{b}}$ & $3.58^{\mathrm{b}}$ & $0.538^{\mathrm{c}}$ & $72.3^{\mathrm{b}}$ \\
$\mathrm{S}_{2}$ & $2.07^{\mathrm{c}}$ & $2.45^{\mathrm{c}}$ & $0.124^{\mathrm{c}}$ & $1.00^{\mathrm{c}}$ & $3.35^{\mathrm{c}}$ & $0.545^{\mathrm{c}}$ & 74.1 \\
$\mathrm{~S}_{3}$ & $2.01^{\mathrm{c}}$ & $2.34^{\mathrm{d}}$ & $0.132^{\mathrm{b}}$ & $0.95^{\mathrm{a}}$ & $3.20^{\mathrm{d}}$ & $0.587^{\mathrm{b}}$ & $72.9^{\mathrm{a}}$ \\
$\mathrm{S}_{4}$ & $2.12^{\mathrm{b}}$ & $2.58^{\mathrm{b}}$ & $0.146^{\mathrm{a}}$ & $0.89^{\mathrm{e}}$ & $3.00^{\mathrm{e}}$ & $0.611^{\mathrm{a}}$ & 73.2 \\
\hline MSE & 0.124 & 0.117 & 0.046 & 0.114 & 0.037 & 0.321 & 0.853 \\
\hline
\end{tabular}

${ }^{*}$ Means within row with no common on letter are significantly different $(p<0.05)$.

There were significant differences $(p<0.05)$ for heart percentage between treatments. Using of herbal plant extract could reduce abdominal fat percentage statistically $(p<0.05)$.Percentage of gizzard was higher in the control group and it was at the lowest in virginiamycine group $(\mathrm{p}<0.05)$. Borsal.f weight percentage was at the lowest on control group and at the highest on $\mathrm{S}_{4}$ group $(\mathrm{p}<0.05)$. Tannins can bind proteins in digestive tracts and reduce protein absorption, thus resulting in deposition of fat in tissue. Landy et al, (2012) showed that carcass yield, gizzard, proventriculus, cecum and small intestine weights, or small intestine and ceca lengths were not markedly affected by dietary treatments.

Table 4 data showed that the triglyceride, cholesterol and LDL level decreased significantly in the treated groups while HDL level increased significantly in S1, S2 ,S3and S4.

Table 4 - The effect of added experimental diets on some blood parameters

\begin{tabular}{ccccc}
\hline Treatments & Triglyceride $(\mathrm{Mg} / \mathrm{dl})$ & Cholesterol $(\mathrm{Mg} / \mathrm{dl})$ & $\mathrm{HDL}(\mathrm{Mg} / \mathrm{dl})$ & $\mathrm{LDL}(\mathrm{Mg} / \mathrm{dl})$ \\
\hline Control $^{\mathrm{S}}$ & $124^{\mathrm{a}}$ & $117^{\mathrm{b}}$ & $124^{\mathrm{c}}$ & $39.80^{\mathrm{a}}$ \\
$\mathrm{S}_{1}$ & $118^{\mathrm{b}}$ & $110^{\mathrm{c}}$ & $118^{\mathrm{a}}$ & $38.45^{\mathrm{c}}$ \\
$\mathrm{S}_{2}$ & $112^{\mathrm{c}}$ & $108^{\mathrm{c}}$ & $125^{\mathrm{c}}$ & $38.68^{\mathrm{b}}$ \\
$\mathrm{S}_{3}$ & $105^{\mathrm{a}}$ & $119^{\mathrm{b}}$ & $132^{\mathrm{b}}$ & $39.10^{\mathrm{a}}$ \\
$\mathrm{S}_{4}$ & $100^{\dagger}$ & $124^{\mathrm{a}}$ & $141^{\mathrm{a}}$ & $37.20^{\mathrm{e}}$ \\
\hline MSE & 8.754 & 6.425 & 7.876 & 3.126 \\
\hline
\end{tabular}

${ }^{\star} M e a n s$ within row with no common on letter are significantly different $(p<0.05)$.

Some scientists found that the virginiamycine had decreased cholesterol, triglycerides and LDL, but it could increase HDL levels in broiler chicks (Ghaedi et al., 2014; Faghani et al., 2014).

Landy et al,(2012) found that the feeding of the broilers with antibiotic resulted in a marked $(\mathrm{P}<0.05)$ increase in total and HDL cholesterol concentration compared to those fed basal diet, or basal diet supplemented with $5 \mathrm{~g} / \mathrm{kg}$ Hypericum perforatum diet. The differences in triglyceride concentration did not reach statistical significance but it tended to decrease in serum of broilers fed diet containing antibiotic.

The antibody titer and intestinal microbial population in control and treated groups is given in Table 5. Antibody titers were significantly higher $(p<0.05)$ when broilers were fed by $S 1, S 2$, S3and S4. It was determined that herbal and virginiamycine had significant effects on $\mathrm{HI}$ test $(p<0.05)$ that compared to control group. Data showed that E. coli population decreased in $S 1$, 
S2, S3 and S4 while Lactobacillus population increased significantly in S4, S3,S2 and S1 respectively $(p<0.05)$.

Table 5 - The effect of experimental diets on antibody titers against new castle vaccine and intestinal microbial population

\begin{tabular}{cccc}
\hline Treatments & E.coli & Lactobacillus & $\mathrm{HI}_{(42 \text { days })}$ \\
\hline & $($ Cfu/g) & $($ Cfu/g) & $3^{(\log )^{\mathrm{d}}}$ \\
Control & $7.25^{\mathrm{a}}$ & $4.69^{\mathrm{e}}$ & $4.17^{\mathrm{c}}$ \\
$\mathrm{S}_{1}$ & $6.97^{\mathrm{b}}$ & $5.54^{\mathrm{b}}$ & $4.31^{\mathrm{b}}$ \\
$\mathrm{S}_{2}$ & $6.79^{\mathrm{c}}$ & $5.45^{\mathrm{c}}$ & $4.35^{\mathrm{b}}$ \\
$\mathrm{S}_{3}$ & $6.58^{\mathrm{d}}$ & $5.20^{\mathrm{d}}$ & $4.68^{\mathrm{a}}$ \\
$\mathrm{S}_{4}$ & $6.20^{\mathrm{e}}$ & $5.78^{\mathrm{a}}$ & 0.856 \\
\hline MSE & 0.634 & 0.914 & \\
\hline
\end{tabular}

*Means within row with no common on letter are significantly different $(p<0.05)$.

Researchers suggested that virginiamycine can controls microbial growth by acting on the mircoflora's biochemical processes such as protein synthesis or inhibiting the elongation of Methono bacterium and $\mathrm{E}$. coli, or by reducing lactic acid producing bacteria in the stomach(Teymourizadeh et al.,2009;Ghaedi et al.,2014 ;Faghani et al.,2014).

Teymourizadeh et al,(2009) and (Ahmadi, 2011) reported that antibiotics, such as virginiamycine, reduce lactic-acid-producing bacteria, which predominate in the upper gastrointestinal tract of the broiler, while lactic acid producing bacteria help in preventing Salmonella.

Also, use of high level of Hypericum perforatum in the diet may have had an adverse effect on some beneficial microbial populations such as lactobacillus, preventing the herb from exhibiting its positive influence on performance and resulting in a poorer FCR (Landy et al.,2012).

As Hypericum perforatum has been reported to have antibacterial, antiviral, and antioxidant activities(Axarlis,1998), an increase in immune responses of chicks was anticipated.

Some studies have reported that Hypericum perforatum had significant therapeutic efficacy and could improve immunologic functions for chickens infected experimentally with IBDV and AIV, respectively (Ruofeng et al., 2012 ; Landy et al., 2012).

Also, (Evstifeeva et al,.., 1996) reported that immunostimulating activity of polyphenolic fraction of Hypericum perforatum with respect to the system of mononuclear phagocyte system, cellular and humoral immunity.

Feizi et al,(2011) found that the use of Hypericum perforatum in each of foregoing doses, has suitable effects on antibody titer increase and this fact is significant between the control group and treatment groups $(\mathrm{P}<0.05)$.

Lavie et al, (1989) identified that Hypercin is an antivirus against attenuator virus of mice immunity.

Based on studies conducted by (Mennini et al., 2004) antiviral and antibiotic effects of the Hypericum perforatum have been proved.

Results of this study are in agreement with (Ahmadi, 2011 and Ghaedi et al, 2014; Faghani et al., 2014; Ghaedi et al.,2014 ; Fiezi et al., 2012 ).

\section{CONCLUSION}

Findings of the present study indicate that using Hypericum perforatum and virginiamycine in the diet of broilers had beneficial effects on performance, intestinal microflora and $\mathrm{HI}$ test. According to our results, dietary supplementation of Hypericum perforatum and virginiamycine could reduce triglyceride, cholesterol and LDL in plasma. It can be concluded that the use of the herb's extract leads to increase immunity level and the rate of antibody titer obtained from 
vaccination against New castle disease. The extract causes to reduce the complications and mortality rate of the disease as well as stress reduction that leads to increase immunity and disease reduction. Although further studies are needed to explore and more detail explanation.

\section{ACKNOWLEDGMENTS}

The authors sincerely acknowledge for the partially helps provided by the Veterinary Clinic Staff of Islamic Azad University ShahreKord Branch.

\section{REFERENCES}

1. Ahmadi, F.2011.The Effect of different levels of Virginiamycin on performance, immune organs and blood metabolite of broiler chickens. Annals of Biological Research, 25: 291-298.

2. Aghili T, Arshami J, Tahmasbi A, Haghparast A .2014. Effects of Hypericum perforatum extract on Ig $\mathrm{G}$ titer, leukocytes subset and spleen index in rats. Avicenna J Phytomed, Epub ahead of print.1-7.

3. Alipour.Sh, Farshadfar.Ez, Amirian.M and Montazeri, M.2013.The effect of St Johnson wort (Hypericum perforatum) extract on the weeds of corn (Zea mays L.) under laboratory condition. Annals of Biological Research. 4 (6):23-28.

4. Axarlis A, Mentis C, Dementzos S, Mitaku AL, Skaltsounis M, Marselos M, Malamas M .1998. Antiviral in vitro activity of Hypericum perforatum L.extracts on the human cytomegalovirus (HCMV). Phytother. Res., 12: 507-511.

5. Bourke, C.1997.Effects of Hypericum perforatum (St. John's wort) on animal health and production. Plant protection quarterly. Vol. 12, (2):91-92.

6. Brenner R, Azbel V, Madhusoodanan S, Pawlowska M.2000. Comparison of an extract of Hypericum (LI 160) and sertraline in the treatment of depression: a double-blind, randomized pilot study. Clin. Ther., 22: 411-419.

7. Duncan, D.B., 1955. Multiple ranges and multiple F. test. Biometric, 11:pp.1-42.

8. Evstifeeva TA, Sibiriak SV.1996. The immunotropic properties of biologically active products obtained from Klamath weed (Hypericum perforatum L.). Eksp. Klin. Farmakol., 59: 51-54.

9. Faghani M, Y Rahimian, A Rafiee and AR Namjoo.2014. Effect of garlic and cinnamon in comparison to virginiamycine on performance and some haematological parameters in broiler chicks. Res. Opin.Anim. Vet. Sci., 4(9): 504-507.

10. Feizi.Adel, Nazeri, M.2011. Evaluation the effect of Hypericum Perforatum dried extract on antibody titer obtained from Newcastle vaccine in broiler chicks. Australian Journal of Basic and Applied Sciences, 5(9): 1261-1265.

11. Ferket PR.2004.Alternatives to antibiotics in poultry production: Responses, practical experience and recommendations. In: Nutritional Biotechnology in the Feed and Food Industries. Lyons TP, Jacques KA (eds). Nottingham University Press, Nottingham, UK, pp. 57-67.

12. Franklin, M., A. Reed and H. Murck, 2004. Sub- chronic treatment with an extract of hypericum perforatum significantly reduces cartisol and corticosterone in the rat brain, European Neurop syehapharmacology, 14: 7-10.

13. Ghaedi H, J Nasr, F Kheiri, Y Rahimian and Y Miri.2014.The effect of virginiamycine and black pepper (Piper nigrum L.) extract on performance of broiler chicks. Res. Opin. Anim. Vet. Sci., 4(2), pp.91-95.

14. Kraus, G.A., D. Pratt, J. Tossberg and S. Carpenter.1990. antiretroviral activity of synthetic hypericin and related analogies, Biochem. Biophys. Res. Commun, 172: 149-153.

15. Landy. N, Ghalamkari .G. H. and Toghyani, M.2012. Evaluation of St John's Wort (Hypericum perforatum L) as an antibiotic growth promoter substitution on performance, 
carcass characteristics, some of the immune responses, and serum biochemical parameters of broiler chicks. Journal of Medicinal Plants Research Vol. 6(3), pp. 510-515.

16. Lavie, G., F. Valentine, B. Levin, Y. Mazur, G. Gallo, D. Lavie, D. Weiner and D. Meruelo, 1989.Studies of the mechanisms of action of the antiretroviral agents hypericin and pseudohypericin, Proc, Natl. Acad. USA.86: 5963-5997.

17. Marounek, M. and V. Rada.1995. Susceptibility of poultry Lactobacilli to lonosphere antibiotics. J.Vet. Med. 42:pp.193-196.

18. Mayahi, M., M.H. Bouzarghmehrifard, 2000.The effect of infectious bursal disease virus and cyclophosphamide on immune respone against Newcastle disease vaccination in broiler chicks. Indian Journal of Animal Sciences, 70: 8-10.

19. Mennini, T. and M. Gobbi.2004. The antidepressant mechanism of Hypericum perforatum, Life science.75: 1021-1027.

20. Ruofeng S, Cheng H, Jiongran C, Xiuying P, Yu L, Lanying H, Ling W, Jianping L.2012. Hypericum perforatum extract therapy for chickens experimentallyinfected with infectious bursal disease virus and its influence on immunity. Can J Vet Res, 76: 180-185.

21. Sakar,M,KM.Tamer,A.U.1990. Antimicrobial activity of different extracts from some Hypericum species, Fitoterapia 61: 464-465.

22. SAS Institute, SAS/STAT User's Guide for Personal Computer.2001.Release 6.12 SAS Institute, Inc., Cary, N.C., USA.

23. Teymourizadeh, Z., Shaaban, R., Karimi, T.M.A. and Beygir, O.2009. The effects of Thymus valgaris L., Echinacea parpurea (L.) moench, Allium sativum L. Extracts and virginiamycine antibiotic on intestinal microflora population and immune system in Broilers. Iranian journal of Medicinal and Aromatic Plants, 25:PP.39-48. 